Kamila Budrowska*

Uniwersytet w Białymstoku

https://orcid.org/0000-0003-3400-3966

\title{
Białostocki urząd cenzury \\ wobec środowiska intelektualnego i kulturalnego regionu w latach 1944-1959. Rekonesans badawczy
}

Streszczenie: Artykuł oparty jest na dokumentach z Archiwum Akt Nowych (zespół GUKPPiW) oraz Archiwum Państwowego w Białymstoku (zespół WUiP oraz UWB). Zebrano w nim informacje o tworzeniu i pracy białostockiego urzędu cenzury w drugiej połowie lat 40. i latach 50. XX wieku i jego wpływie na środowisko intelektualne i kulturalne regionu. Ponadto zasygnalizowano zagadnienia: doświadczenie wojenne i powojenne miasta i regionu, odbudowę życia naukowego, kulturalnego i literackiego, specyfikę cenzorskich raportów oraz cenzorskiego oglądu kontrolowanych treści.

Z badań wynika, że swoje odzwierciedlenie w raportach wojewódzkiego urzędu cenzury znajduje słabość kulturowa regionu.

Słowa-klucze: cenzura; Wojewódzki Urząd Kontroli Prasy, Publikacji i Widowisk w Białymstoku; 1945-1959; województwo białostockie; regionalne środowisko intelektualne.

* Kamila Budrowska - prof. dr hab., pracownik Uniwersytetu w Białymstoku, kierownik Katedry Badań Porównawczych i Edytorstwa. Autorka ponad 100 publikacji naukowych. Interesuje się związkami między literaturą a polityką, cenzurą oraz edytorstwem naukowym. Ostatnio opublikowała monografię Writers, Literature and Censorship in Poland. 1948-1958, przeł. P. A. Vickers, Berlin, Peter Lang 2020. 


\section{Censorship office in Białystok in relation to the intellectual and cultural environment of the region in the years 1944-1959. Reconnaissance study}

Summary: The article is based on documents from the Central Archives of Modern Records (the Main Office for the Control of the Press, Publications, and Public Performances team) and the State Archive in Białystok (the Voivodeship Office of Information and Propaganda team and the University of Białystok team). It presents collected information on the formation and work of the Białystok censorship office in the second half of the 1940s and 1950s, as well as its influence on the intellectual and cultural environment of the region. The article also signals the following issues: war and post-war experiences of the city and the region, restoration of the scientific, cultural and literary life, the specificity of the censorship reports and the censorship view of the controlled contents.

This study shows that the cultural weakness of the region is reflected in the reports of the voivodeship censorship office.

Key words: censorship; Voivodeship Office of Information and Propaganda in Białystok; 1945-1959; Białystok Voivodeship; regional intellectual environment.

\section{Stan badań i założenia badawcze}

Pomimo iż stan badań nad cenzurą ${ }^{1}$ w Polsce Ludowej i PRL-u jest bardzo obszerny, nie pojawiła się odrębna praca na temat działalności oddziału białostockiego ${ }^{2}$. Podstawowa przyczyna wydaje się jasna: nie zachowały

1 System państwowej cenzury był bardzo skomplikowany i obejmował wiele podmiotów $\mathrm{i}$ instytucji. W pierwszych powojennych latach funkcje kontrolne rozproszone były pomiędzy: Ministerstwo Kultury, Ministerstwo Oświaty oraz Ministerstwo Informacji i Propagandy. Stopniowo przechodziły do GUKPPiW, który stał się najważniejszym ogniwem kontroli, zawsze jednak zależnym od dyrektyw partyjnych. W cenzurowanie zaangażowane były ponadto związki twórcze, redakcje, recenzenci, thumacze i sami autorzy.

2 Wyjątkiem jest niepublikowana praca magisterska Karoliny Dudzień-Mróz pt. Cenzurowanie ,,Gazety Białostockiej”. 1951-1975, napisana pod moim kierunkiem naukowym w roku 2010. Autorka oparła się na materiałach z zespołu KW PZPR w Białymstoku, Wydział Propagandy. 
się materiały źródłowe po Wojewódzkim Urzędzie Kontroli Prasy Publikacji i Widowisk w Białymstoku, które umożliwiłyby - w oparciu o jeden bogaty zespół archiwalny - napisanie monografii lub obszernego studium. Spuścizny po urzędach wojewódzkich (zwanych w oficjalnej nomenklaturze urzędu - delegaturami) trafiły na ogół do archiwów państwowych na terenie kraju (najczęściej do archiwum na terenie województwa, gdzie działała dana placówka), ale w Archiwum Państwowym w Białymstoku materiałów po cenzurze brak ${ }^{3}$. Nie udało się, jak dotąd, bezspornie ustalić kiedy i w jakich okolicznościach dokumenty mogły ulec zniszczeniu, czy rozproszeniu, ale prawdopodobne są lata 1989 -1990, kiedy po czerwcowych wyborach w 1989 roku i sejmowej ustawie z kwietnia 1990 roku o likwidacji cenzury, pracownicy urzędu mieli dość czasu, by zniszczyć lub wywieźć obciążające dokumenty ${ }^{4}$. Wiadomo też, że w czasach świetności urzędu istniał proceduralny nakaz niszczenia niektórych typów dokumentów przesyłanych z warszawskiej centrali (na przykład słynnych „książek zapisów i zaleceń") stąd być może niektóre materiały zniszczono na długo przed okresem politycznego przełomu ${ }^{5}$. Zaznaczyć należy, że brak materiałów po wojewódzkim urzędzie cenzury nie dotyczy jedynie byłego województwa białostockiego: podobna sytuacja ma miejsce jeśli chodzi o inne placówki, na przykład wrocławską i szczecińską, co szczególnie bolesne, ze względu na ożywiony ruch literacki w obu tych ośrodkach (we Wrocławiu działało wydawnictwo Ossolineum, czasopismo „Odra”, osiedlili się naukowcy z lwowskiego Uniwersytetu Jana Kazimierza, z kolei Szczecin przeistoczył się po wojnie w pisarską „,kolonię artystyczną" i mógł poszczycić się takimi nowymi mieszkańcami, jak: Jerzy Andrzejewski, Witold Wirpsza, czy Konstanty Ildefons Gałczyński).

Najobszerniejszy zachowany cenzuralny zespół archiwalny to materiały „centrali”: Głównego Urzędu Kontroli Prasy Publikacji i Widowisk w Warszawie, przechowywane w Archiwum Akt Nowych ${ }^{6}$, w którym mieszczą

3 Ustalenia własne. Badania przeprowadzone w ramach grantu „Cenzura wobec literatury polskiej w latach 1945-1989”, NPHR, nr projektu 11 H 11 005280, 2011-2017.

4 Na ten temat: K. Budrowska, Literatura i pisarze wobec cenzury PRL. 1948-1958, Białystok, 2009, s. 17.

5 K. Budrowska, Popietuszko. O najtrudniejszym cenzorskim zadaniu roku 1984, [w:] 1984. Literatura i kultura schytkowego PRL-u, red. K. Budrowska, W. Gardocki, E. Jurkowska, Warszawa 2015, s. 303-304.

6 W 2009 r. liczbę teczek w zespole GUKPPiW szacowałam na 4982, zob. K. Budrowska, Literatura i pisarze, dz. cyt., s. 17. Obecnie dane zostały uściślone przez Patrycję Krasoń, która na 
się dokumenty z kontroli przeprowadzanych w Warszawie oraz przesyłane z oddziałów wojewódzkich. Spora jest też spuścizna po placówkach: poznańskiej, gdańskiej i opolskiej, stąd też te WUKPPiW doczekały się odrębnych monografii. W 2012 roku ukazały się książki Piotra Nowaka Cenzura wobec rynku książki. Wojewódzki Oddział Kontroli Prasy Publikacji i Widowisk w Poznaniu. 1946-1955 oraz Bogusława Gogola „Fabryka fatszywych tekstów”. Z działalności Wojewódzkiego Oddziatu Kontroli Prasy Publikacji i Widowisk w Gdańsku. 1945-1958, a w roku 2019 - praca Mariusza Patelskiego „Czujni strażnicy demokracji” ludowej. Urząd cenzury w województwie opolskim. 1950-19907 . Wymienione opracowania kreślą bogaty obraz środowiska literackiego, księgarskiego, naukowego i artystycznego danych regionów, wskazując przy okazji na specyfikę cenzorskich materiałów i cenzorskiego oglądu sprawy; stanowią też wzór i zachętę do podjęcia wysiłku opisania działalności innych oddziałów.

Szeroka kwerenda własna oraz wykorzystanie stanu badań pozwalają stwierdzić, że pewna część materiałów wytworzonych przez WUKPPiW w Białymstoku - wprawdzie w niekompletności i rozproszeniu, ale się zachowała. Na źródła takie natrafić można w Archiwum Akt Nowych w zespołach GUKPPiW oraz KC PZPR, do których instytucji przesyłano materiały sprawozdawcze, a także w innych archiwach państwowych, gdzie w zespołach innych urzędów wojewódzkich pojawiają się duplikaty białostockich dokumentów, bądź materiały z ocen „krzyżowych” (wykonywanych przez poszczególne oddziały na wzajemne zamówienie). Ponadto, informacje z kontroli dokonywanych w województwie białostockim pojawiają się w zestawieniach zbiorczych,

nowo skatalogowała i opracowała zespół. Liczy on 7867 jednostek archiwalnych. Dla ułatwienia lokalizacji odniesień w artykule podaję starą i nową sygnaturę akt. Na temat prowadzonych prac zob. P. Krasoń, Akta Głównego Urzędu Kontroli Prasy Publikacji i Widowisk w zasobie Archiwum Akt Nowych, [w:] Literatura w granicach prawa (XIX-XX w.), red. K. Budrowska, E. Dąbrowicz, M. Lul, Warszawa 2013, s. 364-376.

7 P. Nowak, Cenzura wobec rynku książki. Wojewódzki Oddziat Kontroli Prasy Publikacji i Widowisk w Poznaniu. 1946-1955, Poznan 2012; B. Gogol, , Fabryka fatszywych tekstów”. Z dziatalności Wojewódzkiego Oddziatu Kontroli Prasy Publikacji i Widowisk w Gdańsku. 1945-1958, Gdańsk 2012; M. Patelski, ,, Czujni strażnicy demokracji” ludowej. Urząd cenzury w województwie opolskim. 1950-1990, Opole 2019. Zob. także na temat oddziału olsztyńskiego: Z. Anculewicz, „Odwilż” w olsztyńskiej cenzurze. Działalność Wojewódzkiego Oddziału Kontroli Prasy, Publikacji $i$ Widowisk w Olsztynie w latach 1954-1958, [w:] Cenzura w PRL. Analiza zjawiska, red. Z. Romek, K. Kamińska-Chełminiak, Warszawa 2017, s. 319-337. 
w których opisuje się funkcjonowanie systemu cenzury na terenie całego kraju: są to protokoły z odpraw krajowych, protokoły z narad poszczególnych działów, materiały instruktażowe (bogate w konkretne przykłady kontroli), spisy wycofanych sztuk. Jako materiał dopełniający wykorzystać można również notatki z działalności organów partyjnych i państwowych szczebla wojewódzkiego. Jeśli chodzi o Białystok, szczególnie interesujące okazały się zespoły Wojewódzkiego Urzędu Informacji i Propagandy w Białymstoku (1944-1947) oraz Urzędu Wojewódzkiego Białostockiego (Wydział Kultury i Sztuki) przechowywane w Archiwum Państwowym w Białymstoku ${ }^{8}$, gdzie jest wiele wzmianek o życiu kulturalnym regionu i kwestiach kontroli. Wydaje się, że liczba dostępnych źródeł jest wystarczająca, by pokusić się o monograficzne ujęcie zagadnienia, co chciałabym postawić jako postulat dalszych działań.

Pomimo braku odrębnej rozprawy o pracy WUKPPiW w Białymstoku, w stanie badań pojawiają się wzmianki na ten temat. Pisząca te słowa, analizując sprawę nigdy nie wystawionej sztuki Dni grozy Rajmunda Hempla, poświęciła kwestii fragment rozprawy Zatrzymane przez cenzurę. Inedita $z$ połowy wieku $X X^{9}$. Anna Artysiewicz o oddziale białostockim wspomina w artykule Cenzorska wizja dramatu i teatru na podstawie „Odpraw krajowych" z lat 1945-194610, a Wiktor Gardocki pisze o cenzorach z tejże placówki w tekście Cenzorzy w latach 1945-1990. Wybrane aspekty pracy ${ }^{11}$. W wielu publikacjach i wypowiedziach pojawia się także propozycja szerszego opracowania zagadnienia.

Niniejszy szkic oparty jest na dokumentach z Archiwum Akt Nowych z zespołu GUKPPiW oraz z Archiwum Państwowego w Białymstoku z zespołów Wojewódzki Urząd Informacji i Propagandy w Białymstoku oraz Urząd Wojewódzki Białostocki. Zadanie, jakie sobie postawiłam to nakreślenie

8 AP w Białymstoku, Wojewódzki Urząd Informacji i Propagandy, sygn. 1-83; AP w Białymstoku, Urząd Wojewódzki Białostocki, Wydział Kultury i Sztuki, sygn. 2332-2389. s. $126-127$.

9 K. Budrowska, Zatrzymane przez cenzurę. Inedita z połowy wieku XX, Warszawa 2013,

10 A. Artysiewicz, Cenzorska wizja dramatu i teatru $w$,Odprawach krajowych” z lat 1945-1946, [w:] Dramat i teatr w dokumentach GUKPPiW, red. K. Budrowska, M. Budnik, K. Kościewicz, Białystok 2017, s. 16.

11 W. Gardocki, Cenzorzy w latach 1945-1990. Wybrane aspekty pracy. Dziękuję Autorowi za udostępnienie artykułu jeszcze przed jego publikacją. 
horyzontu badań: zebranie podstawowych informacji o tworzeniu i pracy białostockiego urzędu cenzury w drugiej połowie lat 40. i latach 50. XX wieku i jego wpływie na środowisko intelektualne i kulturalne regionu. Ponadto zasygnalizowanych zostanie kilka innych zagadnień: specyfika doświadczenia wojennego i powojennego województwa, odbudowa życia naukowego, kulturalnego i literackiego, specyfika cenzorskich raportów oraz cenzorskiego oglądu kontrolowanych treści.

\section{Specyfika doświadczenia wojennego i powojennego regionu}

Specyfika doświadczenia wojennego i powojennego byłego województwa białostockiego wynika z przeżycia dwóch okupacji ${ }^{12}$ : dwukrotnie radzieckiej (od 22 września 1939 do czerwca 1941 oraz po 27 lipca 1944'13) i niemieckiej (od 27 czerwca 1941 do 26 lipca 1944). Wiązała się z tym eksterminacja ludności polskiej przez okupanta rosyjskiego (cztery wielkie fale wywózek w głąb Rosji inteligencji i urzędników, a od lipca 1944 żołnierzy polskiego państwa podziemnego), w latach okupacji niemieckiej nasiliła się eksterminacja ludności żydowskiej. Wedle powszechnego spisu ludności z 1931 roku w Białymstoku mieszkało nieco ponad 90. 000 osób, jesienią 1939 - po przyjęciu fali uchodźców z Polski Centralnej - liczba ludności miasta wzrosła do ok. 200000 osób, z czego ponad 100000 stanowili Żydzi. Wedle spisu z 4 lutego 1946 roku w mieście zostało jedynie 46759 osób.

Po wojnie nastąpiła całkowita zmiana struktury narodowościowej: znikła społeczność żydowska (przyjmuje się, że z getta białostockiego ocalało jedynie ok. 1000 osób oraz kilkuset Żydów z Białostocczyzny, którzy przetrwali wojnę w ZSRR lub na ,aryjskich papierach” i po wojnie wyemigrowali do Izraela lub Stanów Zjednoczonych), pojawiła się natomiast liczna społeczność białoruska (sprowadzona w okresie pierwszej okupacji radzieckiej dla

12 Przygotowując ten fragment artykułu korzystałam z publikacji: Białystok w 80-leciu. W rocznicę odzyskania niepodlegtości 19 luty 1919-19 luty 1999, red. C. Kuklo, Białystok 2000; Białystok nie tylko kulturalny, tomy I i II, red. M. Warda, Białystok 2008; Polska pótnocno-wschodnia w okresie stalinizmu. Spojrzenie z perspektywy pótwiecza, red. K. Sychowicz, E. Świętochowska-Bobowik, W. F. Wilczewski, Białystok-Warszawa 2009.

13 Nie chciałabym w tym miejscu wchodzić w rozważania, czy wejście wojsk radzieckich w lipcu 1944 r. było „wyzwoleniem”, czy „drugą okupacją”, z pewnością nie ustały represje wobec ludności cywilnej. W pamięci zbiorowej Białostocczan okres ten zachował się pod nazwą: „drugie Sowiety". 
osłabienia żywiołu polskiego oraz licznie migrująca do miasta z okolicznych wsi zaraz po wojnie w celu poprawy warunków bytowych). Historycy piszą o wyraźnym antagonizmie pomiędzy ludnością polską a białoruską (stereotyp Białorusina - komunisty, popierającego władzę ludową i stereotyp Polaka narodowca i okrutnika mordującego chłopów białoruskich), co potwierdzają też dokumenty archiwalne ${ }^{14}$. W wyniku działań wojennych miasto zostało poważnie zniszczone, przede wszystkim w związku z likwidacją getta w 1943 roku, podpaleniem centrum przez Niemców w lipcu 1944 przed ofensywą radziecką oraz dywanowymi nalotami lotnictwa ZSRR; centrum miasta zniszczono w $90 \%$.

Walka zbrojna pomiędzy władzą komunistyczną a antykomunistycznym podziemiem trwała $\mathrm{w}$ regionie aż do połowy lat 50 . W sprawozdaniu Wojewódzkiego Urzędu Informacji i Propagandy za okres: styczeń - marzec 1946 czytamy, że w województwie znajduje się jeszcze ok. 9 tysięcy żołnierzy Narodowych Sił Zbrojnych i Narodowej Organizacji Woskowej (potem scalone w Narodowe Zjednoczenie Wojskowe), a w powiatach: sokólskim i wysokomazowieckim znajdują się dwa zakonspirowane pułki AK ${ }^{15}$. Walkę tę symbolicznie zamyka śmierć ppor. Stanisława Marchewki, ps. „Ryba”, poniesiona w nocy z 3 na 4 marca 1957 roku w walce z funkcjonariuszami łomżyńskiej $\mathrm{SB}^{16}$.

\section{Odbudowa życia intelektualnego i kulturalnego}

Odbudowa życia intelektualnego oraz kulturalnego miasta i województwa po II wojnie światowej napotkała na ogromne trudności związane ze słabością środowiska i brakiem elit. Inteligencja polska i żydowska została wywieziona lub wymordowana, po wojnie trudno się było na stale osiedlić (powrócić) ze względu na zniszczenie miasta, porównywane ze zniszczeniem Warszawy. Wprawdzie pierwsze fale repatriantów z terenów Wileńszczyzny i Grodzieńszczyzny pojawiają się już w styczniu 1945, ale większość ludzi jak najśpieszniej udaje się dalej, gdyż nie ma w Białymstoku możliwości zapewnienia

14 AP w Białymstoku, WUIiP, sygn. 6-8.

15 AP w Białymstoku, WUIiP, sygn. 6.

16 Polska pótnocno-wschodnia w okresie stalinizmu. Spojrzenie z perspektywy półwiecza, dz. cyt., s. 7 (wstęp). 
minimalnych choćby warunków bytowych. Przykładowo, w latach 1944-1947 czasowo przebywali w Białymstoku znani aktorzy: Ludwik Sempoliński, Igor Śmiałowski (17 kwietnia 1945 roku wziął ślub w katedrze białostockiej), Hanka Bielicka, Zygmunt Kęstowicz z żoną, Czesław Wołłejko, Marian Meller. Analizując materiały cenzorskie dotyczące kontroli teatrów amatorskich natrafiłam na ślad innej aktorskiej „kolonii artystycznej” funkcjonującej w Ełku przez kilka miesięcy roku $1948^{17}$.

Na dłużej pozostała w regionie tak zwana „grupa wileńska”, z arcybiskupem Romualdem Jałbrzykowskim, metropolitą wileńskim oraz profesorami seminarium duchownego na czele. Arcybiskup Jałbrzykowski przybył do Białegostoku 15 lipca 1945 roku i już w tym samym roku uruchomiło swoją działalność seminarium duchowne, pierwsza wyższa szkoła w regionie. Kolejną uczelnię wyższą - Akademię Medyczną - powołano do życia w lutym 1950, jako dziesiąty wydział medyczny w kraju.

W kwestionariuszu wypełnionym przez naczelnika Wydziału Kultury i Sztuki Urzędu Wojewódzkiego w Białymstoku w czerwcu 1945 roku czytamy, że nie ma w regionie warunków do przyjęcia gości z odczytami, a konkurs na pisarzy ludowych też nie przyniósł spodziewanych efektów. Lepiej wygląda natomiast życie teatralne: w Białymstoku pracuje jeden teatr zawodowy, a w województwie istnieje aż siedem teatrów amatorskich ${ }^{18}$.

Z innych źródeł wynika, że w mieście funkcjonował ponadto Wojewódzki Teatr Kukiełkowy (założony 1 sierpnia 1944 roku przez Stefana Niewiadomskiego) ${ }^{19}$ oraz prywatny teatr dziecięcy Tamary Szumskiej20.

W pierwszych latach po wojnie nie ma także w regionie prasy literackiej. Jadwiga Sadowska ocenia, że w dekadzie 1944-1953 ukazywało się w Białostockiem 18 tytułów, ale były to pisma codzienne, branżowe, jednodniówki oraz biuletyny tworzącej się administracji państwowejej ${ }^{21} \mathrm{Z}$ ważniejszych tytułów

17 K. Budrowska, Zatrzymane przez cenzurę..., dz. cyt., s. 125. Sprawa wymaga dalszych dociekań.

18 AP w Białymstoku, UWB, Wydział Kultury i Sztuki, sygn. 2332, k. 17-20.

19 AP w Białymstoku, UWB, Wydział Kultury i Sztuki, sygn. 2386.

20 AP w Białymstoku, UWB, Wydział Kultury i Sztuki, sygn. 2387.

21 J. Sadowska, Prasa regionu białostockiego w latach 1944-2012, [w:] Prasa województwa podlaskiego w latach 1944-2012, red. J. Sadowska, K. Sawicka-Mierzyńska, Białystok 2014, s. 54. 
należy przywołać „Jedność Narodową”, która wychodziła w latach 1944-1947 (od 1946 z podtytułem ,pismo codzienne Województwa Białostockiego”), prawdopodobnie nielegalną „Patrię: pismo żołnierskie” - organ organizacji „Wolność i Niezawisłość” (1946), „Życie Białostockie” - regionalną mutację „Życia Warszawy” (1947-1956), „Wiadomości Archidiecezjalne” (wydawane od 1947, zawieszone w $1948 \mathrm{w}$ okresie stalinizacji i wznowione w 1957) ${ }^{22}$.

Kolportażem prasy ogólnokrajowej zajmował się oddział spółdzielni „Czytelnik”23. Jak wynika ze źródeł archiwalnych, w drugiej połowie lat 40. na terenie województwa nie działa żadne wydawnictwo, poza branżowymi i związków wyznaniowych, nie pracuje ani jeden czynny literat, a jedynie tak zwani „twórcy samorodni”, otoczeni ministerialną opieką. Próbą ożywienia ruchu literackiego było ogłoszenie w styczniu 1946 roku przez „Jedność Narodową” konkursu literackiego, który nie przyniósł jednak przełomowych rezultatów ${ }^{24}$.

Socrealistyczny opis miasta i regionu dokonany został także przez przybyszy z zewnątrz. W czasie akcji wysyłania pisarzy w teren do fabryki sklejek w Białymstoku skierowana została Joanna Żwirska ${ }^{25}$, a autorem powieści Herkulesy o środowisku studentów Akademii Medycznej i konflikcie klasowym między nimi - warszawianin Jerzy Stefan Stawiński, słynny scenarzysta, autor scenariusza między innymi do Kanału Andrzeja Wajdy ${ }^{26}$.

Niewielkie ożywienie kulturalne nastąpiło na Białostocczyźnie w latach 50., zwłaszcza pod koniec dekady. Codzienna „Gazeta Białostocka” (organ KW PZPR) ukazywała się od 1951 roku, a pierwszy numer białoruskiego tygodnika „Niwa” wyszedł w marcu 1956 roku. Warto dodać, że 1956 roku i „odwilż" nie miały w województwie dramatycznego przebiegu, stąd brak idącego za nimi fermentu intelektualnego, związanego z demontażem socrealizmu ${ }^{27}$.

22 J. Sadowska, dz. cyt., s. 56-58.

23 AP w Białymstoku, WUIiP, sygn. 8.

24 AP w Białymstoku, WUIiP, sygn. 6.

25 AP w Białymstoku, UWB, Wydział Kultury i Sztuki, sygn. 2377, k. 136.

26 J. S. Stawiński, Herkulesy, Warszawa 1955. Na ten temat: J. Smulski, Dwie zapomniane powieści uniwersyteckie. Przyczynek do dziejów realizmu socjalistycznego w Polsce, [w:] tegoż, Rozmaitości socrealistyczne (i nie tylko), Torun 2015, s. 118-140.

27 T. Danilecki, Specyfika przemian 1956 r. na Białostocczyźnie, [w:] Polska pótnocno-wschodnia w okresie stalinizmu. Spojrzenie z perspektywy półwiecza, red. K. Sychowicz, E. Świętochowska-Bobowik, W. F. Wilczewski, Białystok-Warszawa 2009. 


\section{WUKPPiW w Białymstoku i jego działalność}

Na zjeździe Delegatów Wojewódzkich i Miejskich Biur Kontroli Prasy w dniach 23, 24 i 25 maja 1945 roku podaje się, że białostockie biuro zorganizowano 28 lutego 1945 roku. Obecna na zjeździe pierwsza pracownica oddziału, Sabina Lewi, tak charakteryzuje teren swojej pracy: „Nasze województwo pod względem kultury słabo się przedstawia, chociaż pod innymi ma bogatą kartę" $[. . .]^{28}$. Opisując najważniejsze ingerencje z 1945 roku, w tym w dramat Gabrieli Zapolskiej, zdradza się z niskim poziomem intelektualnym, z czego można wnosić o jej słabym wykształceniu:

[...] Nie pozwoliłam wystawiać sztuki „Tamten”. Sztuka ta jest stara z 1902 r. i omawia warunki życia Polaków w Rosji, Sybir, kajdany, itp. Jako cenzor zajęłam stanowisko, że jakkolwiek potępiam ucisk carski i potępia go również Rząd Sowiecki, ale w tym momencie wysuwać momenty przeciwko narodowi rosyjskiemu. My chcemy mieć stosunki przyjazne i nie leży w interesach demokracji żeby przypominać rany jątrzące. [...]. [...] Miałam zapytanie ze strony pełnomocnika czy należy zezwalać na wywieszanie afiszów w sprawie przyjmowania wróżki. Zezwoliłam, ponieważ uważałam, że jeśli nie dam zezwolenia to będą to robić w ukryciu. [...] $]^{29}$.

Biogram Sabiny Lewi pojawia się w pracy Twarze białostockiej bezpieki: ,[...] ur. w 1910 roku. Przebieg służby: referent Sekcji 1 WUPB w Białymstoku (od 14 IX 1944 roku); kierownik Biura Kontroli Prasy i Wydawnictw WUBP w Białymstoku (od 24 II 1945 roku); naczelnik Wydziału Cenzury WUBP w Białymstoku (od 20 III 1945 roku); w dyspozycji Centralnego Biura Prezydium KRN (od 31 I 1946 roku)"30.

Po przejściu Sabiny Lewi na inne stanowisko, naczelnikiem został Stefan Hardej (od 1946 do sierpnia 1950 roku), 2 stycznia 1954 roku jego miejsce zajął Jan Jantas ${ }^{31}$. Obowiązki cenzorskie pełniła w tym czasie, nieznana

28 AAN, GUKPPiW, 421, teczka 197/1, k. 27; nowa sygnatura: 1.

29 AAN, GUKPPiW, 421, teczka 197/1, k. 30-31; nowa sygnatura:1.

30 Twarze biatostockiej bezpieki. Obsada stanowisk kierowniczych Urzędu Bezpieczeństwa i Stuzby Bezpieczeństwa w Białymstoku. Informator Personalny, red. P. Łapiński, Białystok 2007, s. 160.

31 Nie udało się ustalić, kto był naczelnikiem pomiędzy nimi. 
z imienia, towarzyszka Chrzanowa. W drugiej połowie lat 50. w WUKPPiW w Białymstoku pracowali ponadto: cenzor Wiesław Radomski , cenzor Mieczysław Żaczek i sekretarka o nazwisku Borowik.

Należy zwrócić uwagę na słabości kadrowe i - dla porównania - podać, że w Krakowie wszyscy cenzorzy w roku 1959 mają wyższe wykształcenie. W lipcu 1959 roku pisze zaś naczelnik Jantas (sam uzyskał maturę po 4 latach pracy w cenzurze):

Nie udało nam się tylko nakłonić tow. Żaczka Mieczysława do uczęszczania do gimnazjum zamkniętego dla pracujących jakie ostatnio zostały zorganizowane. Ciężko mu jakoś przyłożyć się do nauki, a bardzo mu jest potrzebna ${ }^{32}$,

a pół roku później:

[...] do poważniejszych prac nie garnie się 33 .

Jak ustalił Wiktor Gardocki, biogramy białostockich funkcjonariuszy kryją wiele interesujących szczegółów dotyczących pochodzenia, wykształcenia oraz dalszego przebiegu kariery ${ }^{34}$.

Zasadą było, że delegatura wojewódzka cenzuruje publikacje i widowiska ze swego terenu oraz przeprowadza kontrolę wtórną, rzadziej pierwotną, materiałów $\mathrm{z}$ innych regionów. W Białymstoku były to najczęściej materiały z Lublina i Rzeszowa. Ścisłe związki z oddziałem w Lublinie i Rzeszowie można wiązać z osobą Stefana Hardeja, który kolejno obejmował tam stanowiska naczelnika (w 1950 w Lublinie, w 1953 w Rzeszowie).

W związku ze słabością środowiska intelektualnego województwa, WUKPPiW w Białymstoku nie miał $\mathrm{w}$ drugiej połowie lat 40 . wiele pracy, a cenzorzy skupiali się przede wszystkim na kontroli widowisk i prasy. Nie zachowały się

32 AAN, GUKPPiW, 592, teczka 63/1, k. 7; nowa sygnatura: 14.

33 Dz. cyt., k. 9; nowa sygnatura: 14.

34 W. Gardocki, dz. cyt. Teczki osobowe cenzorów na potrzeby publikacji „,Biuletyn Informacyjno-Instrukcyjny”. Wybór dokumentów z roku 1955, red. K. Budrowska, M. Budnik, W. Gardocki, Białystok 2018, przejrzeli Magdalena Budnik i Wiktor Gardocki. Biogramy zostały w książce opublikowane w wersji okrojonej, ze względu na ustawę o ochronie danych osobowych. Dziękuję Autorom biogramów za udostępnienie ich pełnych wersji na potrzeby niniejszego tekstu. 
wprawdzie dokumenty z kontroli sztuk wystawianych w kilku teatrach zawodowych, ale w źródłach znajduje się informacja, że na każdym przedstawieniu sześć miejsc podlegało rezerwacji dla przedstawicieli władz i cenzury ${ }^{35}$. W sierpniu 1948 roku Stefan Hardej odsyła do oceny do Urzędu Wojewódzkiego dramat nieznanego autora Młode orly, co wskazuje na przemieszanie kompetencji oraz faktyczną podległość WUKPPiW wobec instancji partyjnych.

Od początku lat 50. codziennie kontrolowano „Gazetę Białostocką”, regularnie przygotowywano kontrolę wtórną prasy rzeszowskiej, oceniano broszury religijne, kalendarze i codzienny godzinny program regionalnej rozgłośni radiowej. Z zachowanej dokumentacji wynika, że nadal sporo czasu poświęcano na kontrolę widowisk, w tym repertuaru miejskiego stałego teatru (w roku 1949 uzyskał oficjalną nazwę: „Teatr imienia Aleksandra Węgierki”), występów gościnnych, a także repertuaru zespołów amatorskich, w tym tak zwanych „dzikich" (niezarejestrowanych) ${ }^{36}$. Ponadto dokonywano regularnych inspekcji terenowych, na przykład w pierwszym półroczu 1959 roku - do skutku doszło osiemnaście wyjazdów.

Jeśli chodzi o publikacje nieperiodyczne, to miał WUKPPiW w Białymstoku niewiele pracy. Przez pół roku skontrolowano tu jedynie trzydzieści kilka pozycji, czyli sześć książek miesięcznie, dla porównania można dodać, że w oddziale krakowskim w ciągu miesiąca czytano w latach 50. około osiemdziesięciu tytułów. Naczelnik Jantas tłumaczy to ,[...] brakiem żywszych środowisk kulturalnych na Białostocczyźnie" i trudno nie zgodzić się z jego opinią.

\section{Sprawozdanie WUKPPiW w Bialymstoku z 1959 roku}

Poddane analizie sprawozdanie z działalności WUKPPiW w Białymstoku przechowywane jest w Archiwum Akt Nowych w zespole GUKPPiW ${ }^{37}$. Składa się z dwóch części i obejmuje pierwsze i drugie półrocze 1959 roku. Dokument, oznaczony jako „tajny”, sporządzony został 11 lipca 1959 roku (część I) oraz 7 stycznia 1960 (część II) i podpisany przez naczelnika Jantasa.

35 AP w Białymstoku, UWB, Wydział Kultury i Sztuki, sygn. 2332.

$36 \mathrm{Na}$ ten temat zob. B. Tyszkiewicz, „Dzikie zespoty” $i$ ocenzurowany cyrk. GUKPPiW wobec wybranych zjawisk kultury popularnej, [w:] Kultura popularna w Polsce 1944-1989. Między projektem ideologicznym a kontestacją, red. K. Stańczak-Wiślicz, Warszawa 2015, s. 11-41.

37 AAN, GUKPPiW, 592, t. 63/1; nowa sygnatura: 14. 
Maszynopis liczy łącznie trzynaście i pół strony; zawiera liczne podkreślenia, można sądzić, że dokonano ich już w urzędzie centralnym, dla wyróżnienia ważniejszych sformułowań.

Cenzorskie zestawienia zbiorcze są szczególnie interesującym źródłem do badań nad ogólnopolskim i regionalnym ruchem intelektualnym, kulturalnym i wydawniczym. Rejestrują - w trybie miesięcznym, półrocznym i rocznym - całość cenzorskich działań: cały kraj i wszystkie typy działalności kontrolnej (prasa, literatura piękna, literatura naukowa, widowiska, radio). Przy czym, opisują nie tylko przekazy dopuszczone do publikacji, ale i te, do których realizacji nie doszło. Niejednokrotnie stanowią jedyne źródło informacji na dany temat, niedający się potwierdzić - w związku z rozproszeniem, niekompletnością i trudnym dostępem do dokumentacji - w innych materiałach. Szczególnie cenne wydają się zestawienia zbiorcze dokonanych ingerencji oraz wykazy tekstów zatrzymanych w całości: dzięki ich analizie udało się ustalić istnienie licznych tekstów niewydanych za życia autorów, a o których istnieniu nic nie było dotąd wiadomo ${ }^{38}$.

Zestandaryzowane raporty budują zwartą i systemowo przekazywaną do GUKPPiW informację na temat ilościowych i jakościowych efektów pracy podległych jej jednostek, stanowią więc znakomity materiał do analizy pracy urzędów wojewódzkich. Pośrednio - informują także o wydarzeniach kulturalnych i ruchu wydawniczym w regionach. Naczelnicy terenowi piszą sprawozdania wedle następującego porządku: Organizacja pracy WUKP, O zadaniach podstawowych i ocenach, $\mathrm{O}$ zadaniach zleconych, $\mathrm{O}$ zadaniach specjalnych, Sprawa na odcinku katolickim, Samokształcenie ideologiczne, partyjne, zawodowe, Instruktaż bieżący, Jak pracowano z nowoprzyjętymi, Trudności na jakie natknął się WUKP w swej pracy, Współpraca z GUKP, Uwagi o kontroli GUKP, Uwagi naczelnika o ostatnim numerze biuletynu (chodzi o biuletyn instrukcyjno-szkoleniowy ${ }^{39}$ ). Opis środowisk intelektualnych i działań twórczych czyniony jest zatem w sposób specyficzny: pisze się głównie o brakach i przeoczeniach. Dzięki takiemu ukształtowaniu dokumentów mamy z jednej strony wgląd $w$ to, co było przez stronę partyjno-rządową narzucane i z drobiazgowością planowane, a z drugiej strony w to, jak środowiska lokalne cenzurę

39 Zob. „Biuletyn Informacyjno-Instrukcyjny”. Wybór dokumentów z roku 1955, dz. cyt., s. 7 i nast. 
„sondowały" i jak próbowano przesuwać granice tego, co dozwolone. Naczelnik opisuje ponadto system pracy oddziału (godziny, obowiązki cenzorskie, wyjazdy w teren), kwestie kadrowe (dokształcanie się kadry cenzorskiej, zaangażowanie w pracę) oraz bytowe - skarży się brak mieszkań i dziękuje za już uzyskane.

W pierwszym półroczu 1959 roku w WUKPPiW w Białymstoku dokonano dwudziestu dziewięciu ingerencji w prasie terenowej (jako przeoczenie odnotowano niewykreślenie numeru jednostki wojskowej), w drugim półroczu - trzydziestu trzech ingerencji. Można zatem stwierdzić, że „Gazeta Białostocka” i „Niwa” nie nastręczały cenzorom wiele pracy, a redakcje były „dobrze upolitycznione". Ciekawa wydaje się także informacja o próbie powołania nowej gazety „Wieś Białostocka”, na którą GUKPPiW się nie zgodził.

Ingerencje w wydawnictwa nieperiodyczne ograniczały się do broszur, kalendarzy, materiałów związków wyznaniowych: Kościoła katolickiego i Świadków Jehowy - te ostatnie na prośbę prokuratury, gdyż związek działał nielegalnie, kryminalnych powieści publikowanych w odcinkach na łamach „Gazety Białostockiej” oraz prac naukowych Akademii Medycznej i Zakładu Badana Ssaków Polskiej Akademii Nauk w Białowieży.

Naczelnik Jan Jantas skarży się centrali na działania Kurii i księży pracujących w poszczególnych parafiach. „Wiadomości Kościelne” próbowały „przeforsować zbiór encyklik związanych z kultem matki Boskiej” i zszyć pięć zeszytów w całość, czyniąc z nich broszurę. Działania te udaremniono.

Na ogół w województwie Białostockiem sprawy katolickie kształtują się nierównomiernie. Kler przy odpowiedniej polityce opanowuje się dość szybko. Ale są miejscowości i środowiska więcej sfanatyzowane, więcej zacofane - tam też i księża znajdują większy posłuch ${ }^{40}$.

„Niesubordynowani” księża przygotowali jasełka (ksiądz Gniedziejko w parafii w Łapach), przedstawienia religijne, na przykład: Bernadetta (ksiądz Henryk Glinko w parafii w Mońkach), czy Misterium Męki Pańskiej (ksiądz Wróblewski w powiecie łapskim).W Krynkach dramat Gość oczekiwany Zofii Kossak-Szczuckie wystawił, własnymi siłami i bez zezwolenia,

40 AAN, GUKPPiW, 592, teczka 63/1, k. 5; nowa sygnatura: 14. 
chór kościelny. Poza tym, nielegalnie wydrukowano zdjęcia biskupa przed jego wizytą w parafii Gołdap i sprzedawano je w cenie po pięć i po dwa złote (zdjęcia skonfiskowano, a do Komisji Walki ze Spekulacją skierowano wnioski o ukaranie winnych). Księża odpowiedzialni za przygotowanie niecenzuralnych i nieocenzurowanych przedstawień zostali ukarani wysokimi grzywnami.

W drugiej połowie lat 50. w Białymstoku działały: teatr miejski, teatr lalkowy, kina, regionalna rozgłośnia radiowa, jednakże cenzorskie sprawozdania tego nie odzwierciedlają. Wspomina się w nich jedynie o występach estradowych i wizytach zespołów objazdowych, podając informacje o niewielkich ingerencjach (na przykład piosenka tytułowa z programu Docelowo Ziemowita Kamińskiego i Jerzego Medyńskiego). Najwyraźniej repertuar stałych teatrów i kin nie zatrzymał uwagi kontrolujących.

Przyczyn niskiego poziomu rozwoju kulturalnego regionu w latach 40. i 50. upatrywać należy w jego dramatycznej historii, stratach ludnościowych i materialnych oraz wojennej i powojennej migracji, którą historycy nazywają nawet „exodusem”41. Ta słabość życia znajduje swoje odzwierciedlenie i w cenzorskim zestawieniu. Białostocka delegatura żyje w 1959 roku walką $\mathrm{z}$ amatorskimi przedstawieniami o treści religijnej, kryminalnymi powieściami drukowanymi w odcinkach w „Gazecie Białostockiej”, kalendarzami i jednodniówkami.

\section{Wnioski}

Z przeglądu najważniejszych zagadnień dotyczących pracy białostockiego oddziału urzędu cenzury w pierwszych latach po wojnie wynika kilka wniosków.

1. Materiałów archiwalnych jest na tyle dużo, by pokusić się o przygotowanie monografii. Opracowanie takie mogłoby być zogniskowane, podobnie jak praca Piotra Nowaka, wokół zagadnień życia intelektualnego i kulturalnego regionu z uwzględnieniem państwowej kontroli słowa albo - wzorem monografii Bogusława Gogola i Mariusza Patelskiego - wokół opisania działań WUKPPiW w Białymstoku, z większym naciskiem na odtworzenie organizacji urzędu kontroli i jego powiązań z systemem komunistycznej

41 T. Danilecki, Specyfika przemian 1956 r. na Białostocczyźnie, dz. cyt., s. 153. 
władzy. Przy czym, można wyobrazić sobie opracowanie obejmujące całość działań białostockiej delegatury na przestrzeni lat 1945-1990 lub wycinek tego czasu.

2. O ile, w związku ze słabością ruchu wydawniczego w regionie, odtworzenie działań urzędu kontroli nie będzie miało przełomowego znaczenia dla ustaleń historycznoliterackich, o tyle dla uzupełnienia wiedzy o dziejach regionu - już tak. Analiza materiałów archiwalnych związanych z pracą WUKPPiW w Białymstoku pozwala bowiem na wprowadzenie do naukowego obiegu faktów niedających się potwierdzić w innych źródłach.

3. W opisywanych latach tużpowojennych największą aktywność przejawiały teatry, zarówno zawodowe, jak i amatorskie. Wątek cenzurowania życia teatralnego regionu może przynieść istotne ustalenia, wymaga jednak dalszych kwerend.

\section{Bibliografia}

\section{Źródła}

AAN, GUKPPiW, 421, teczka 197/1; nowa sygnatura: 1.

AAN, GUKPPiW, 592, teczka 63/1; nowa sygnatura: 14.

AP w Białymstoku, Urząd Wojewódzki Białostocki, Wydział Kultury i Sztuki, sygn. 2332-2389.

AP w Białymstoku, Wojewódzki Urząd Informacji i Propagandy, sygn. 1-83.

Dudzień-Mróz K., Cenzurowanie "Gazety Białostockiej”. 1951-1965, niepublikowana praca magisterska napisana pod kierunkiem dr K. Budrowskiej, Białystok, Uniwersytet w Białymstoku, 2010.

\section{Publikacje}

Anculewicz Z., "Odwilż” w olsztyńskiej cenzurze. Działalność Wojewódzkiego Oddziału Kontroli Prasy Publikacji i Widowisk w Olsztynie w latach 1954-1958, [w:] Cenzura w PRL. Analiza zjawiska, red. Z. Romek, K. Kamińska-Chełminiak, Warszawa 2017. 
Artysiewicz A., Cenzorska wizja dramatu i teatru w "Odprawach krajowych" z lat 1945-1946, [w:] Dramat i teatr w dokumentach GUKPPiW, red. K. Budrowska, M. Budnik, K. Kościewicz, Białystok 2017.

Białystok nie tylko kulturalny, tomy I i II, red. M. Warda, Białystok 2008.

Białystok w 80-leciu. W rocznicę odzyskania niepodległości 19 luty 1919-19 luty 1999, red. C. Kuklo, Białystok 2000.

„Biuletyn Informacyjno-Instrukcyjny". Wybór dokumentów z roku 1955, red. K. Budrowska, M. Budnik. W. Gardocki, Białystok 2018.

Budrowska K., Literatura i pisarze wobec cenzury PRL. 1948-1958, Białystok 2009.

Budrowska K., Popiełuszko. O najtrudniejszym cenzorskim zadaniu roku 1984, [w: ] 1984. Literatura i kultura schyłkowego PRL-u, red. K. Budrowska, W. Gardocki, E. Jurkowska, Warszawa 2015.

Budrowska K., Zatrzymane przez cenzurę. Inedita z połowy wieku XX, Warszawa 2013.

Danilecki T., Specyfika przemian 1956 r. na Białostocczyźnie, [w:] Polska północno-wschodnia w okresie stalinizmu. Spojrzenie z perspektywy półwiecza, red. K. Sychowicz, E. Świętochowska-Bobowik, W. F. Wilczewski, Białystok-Warszawa 2009 , s. 30-49.

Gardocki W., Cenzorzy w latach 1945-1990. Wybrane aspekty pracy, w druku.

Gogol B., "Fabryka fałszywych tekstów”. Z działalności Wojewódzkiego Oddziału Kontroli Prasy Publikacji i Widowisk w Gdańsku. 1945-1958, Gdańsk 2012.

Krasoń P., Akta Głównego Urzędu Kontroli Prasy Publikacji i Widowisk w zasobie Archiwum Akt Nowych, [w:] Literatura w granicach prawa (XIX-XX w.), red. K. Budrowska, E. Dąbrowicz, M. Lul, Warszawa 2013, s. 364-376.

Nowak P., Cenzura wobec rynku książki. Wojewódzki Oddział Kontroli Prasy Publikacji i Widowisk w Poznaniu. 1946-1955, Poznań 2012.

Patelski M. , „Czujni strażnicy demokracji” ludowej. Urząd cenzury w województwie opolskim. 1950-1990, Opole 2019.

Polska północno-wschodnia w okresie stalinizmu. Spojrzenie z perspektywy półwiecza, red. K. Sychowicz, E. Świętochowska-Bobowik, W. F. Wilczewski, BiałystokWarszawa 2009.

Sadowska J., Prasa regionu białostockiego w latach 1944-2012, [w:] Prasa województwa podlaskiego w latach 1944-2012, red. J. Sadowska, K. Sawicka-Mierzyńska, Białystok 2014, s. 53-183. 
Smulski J., Dwie zapomniane powieści uniwersyteckie. Przyczynek do dziejów realizmu socjalistycznego w Polsce, [w:] tegoż, Rozmaitości socrealistyczne (i nie tylko), Toruń 2015, s. 118-140.

Stawiński J.S., Herkulesy, Warszawa 1955.

Twarze białostockiej bezpieki. Obsada stanowisk kierowniczych Urzędu Bezpieczeństwa i Służby Bezpieczeństwa w Białymstoku. Informator Personalny, red. P. Łapiński, Białystok 2007.

Tyszkiewicz B., „Dzikie zespoły” i ocenzurowany cyrk. GUKPPiW wobec wybranych zjawisk kultury popularnej, [w:] Kultura popularna w Polsce 1944-1989. Między projektem ideologicznym a kontestacją, red. K. Stańczak-Wiślicz, Warszawa 2015, s. 11-41. 